Article

\title{
Fire Recurrence and Normalized Difference Vegetation Index (NDVI) Dynamics in Brazilian Savanna
}

\author{
Níckolas Castro Santana \\ Departamento de Geografia, Campus Universitário Darcy Ribeiro, Asa Norte, Universidade de Brasília (UnB), \\ DF 70910-900 Brasília, Brazil; nickolas.santana@outlook.com
}

Received: 12 November 2018; Accepted: 17 December 2018; Published: 21 December 2018

\begin{abstract}
Fire is one of the main modeling agents of savanna ecosystems, affecting their distribution, physiognomy and species diversity. Changes in the natural fire regime on savannas cause disturbances in the structural characteristics of vegetation. Theses disturbances can be effectively monitored by time series of remote sensing data in different terrestrial ecosystems such as savannas. This study used trend analysis in NDVI (Normalized Difference Vegetation Index)-MODIS (Moderate Resolution Imaging Spectroradiometer) time series to evaluate the influence of different fire recurrences on vegetation phenology of the Brazilian savanna in the period from 2001 to 2016. The trend analysis indicated several factors responsible for changes in vegetation: (a) The absence of fire in savanna phytophysiognomies causes a constant increase in MODIS-NDVI, ranging from 0.001 to 0.002 per year, the moderate presence of fire in these areas does not cause significant changes, while the high recurrence results in decreases of MODIS-NDVI, ranging from -0.002 to -0.008 per year; (b) Forest areas showed a high decrease in NDVI, reaching up to -0.009 MODIS-NDVI per year, but not related to fire recurrence, indicating the high degradation of these phytophysiognomies; (c) Changes in vegetation are highly connected to the protection status of the area, such as areas of integral protection or sustainable use, and consequently their conservation status. Areas with greater vegetation conservation had more than $70 \%$ of positive changes in pixels with significant tendencies. Absence or presence of fire are the main agents of vegetation change in areas with lower anthropic influence. These results reinforce the need for a suitable fire management policy for the different types of Cerrado phytophysiognomies, in addition to highlighting the efficiency of remote sensing time series for evaluation of vegetation phenology.
\end{abstract}

Keywords: burned area; MODIS time-series; vegetation index; Cerrado; Jalapão

\section{Introduction}

Fire is a key agent in the ecological processes of biomes, changing the distribution and structure of vegetation, with the regulation of forest and savanna species, and modifying carbon-climate cycles at regional and global levels, as a result of greenhouse gases and aerosol emissions and the consequent alteration of the surface radiation balance [1,2]. Mosaics of forests and savannas, dependent on the absence or presence of fire to maintain their structure and plant diversity, were created from the result of fire in terrestrial ecosystems [3]. Interaction of fire with the biomes resulted in decrease of tree biomass, allowing the emergence of savanna ecosystems with high diversity, supported by domain of grass and shrub species, attenuation of competitive exclusion, expansion of landscape diversity and generation of new niches $[4,5]$. 
Each type of savanna formation has an ideal fire recurrence to maintain its high productivity, ranging, for example, from three years to ten in South Africa savannas [6,7], from two to ten years in tropical savannas of northern Australia [8] and from two to nine years in Brazilian savannas [9], as well as a fire recurrence above the environmental regeneration limit causing the alteration of important components of soil, fauna and flora.

Fire events associated with strong climatic seasonality were the main factors responsible for the original configuration of Brazilian savannas, locally known as Cerrado [10]. Cerrado species are adapted in different ways to long periods of drought and diverse physical conditions of the soil, resulting in a mosaic of phytophysiognomies from grassy fields, very resistant to high intensity fires, to closed forests, with high plant diversity in areas of nutrient-rich soils [11,12].

Several Cerrado species require fire for seed germination or for elimination of competing species, but they do not tolerate events of high recurrence, resulting in a decrease in number of new sprouts and high mortality rates in areas with tree species [13]. In contrast, fire exclusion in fire dependent areas causes loss of diversity with establishment of forest species with low fire resistance [14,15]. In addition to the fragility of certain species to changes in fire regime, the Brazilian Cerrado has been highly degraded, with high rates of deforestation and fragmentation [16-18].

Protected areas of Brazilian Cerrado are not well distributed throughout the territory; few of the areas have more than 25,000 ha, resulting in low connectivity and low biome protection. More than $50 \%$ of Cerrado has been converted into pastures and agricultural lands in the last decades, with more than $70 \%$ of the remaining vegetation showing some decline [17]. The decline of vegetation productivity can be related to human factors such as soil degradation, deforestation and conversion of natural vegetation, or associated with natural factors such as climate and fire. The decrease in tree density in global savannas has been demonstrated as a result of high fire recurrence events and degradation of vegetation [19].

Vegetation parameters, such as the description of phenological patterns, can be estimated from time series of vegetation indexes derived from remote sensing, and among them, NDVI (Normalized Difference Vegetation Index) [20] has been widely used to monitor vegetation dynamics. There are studies that have examined, for example, the beginning and end periods of the vegetation growing season [21,22], the evaluation of selective cutting effects and climate change on vegetation [23-25], and the evaluation of post-fire effects and regeneration of vegetation [26-28]. Time series of indices such as NDVI are influenced by climate and surface changes, besides being vulnerable to noise such as atmospheric effects and different acquisition angles [25,29]. Trend detection in time series relies on filtering the series for noise attenuation, as well as in the detection of changes from regression methods, temporal autocorrelation or non-parametric methods such as the Mann-Kendall test [30].

Most of the studies that evaluated the influence of disturbances on vegetation temporal dynamics are concentrated in areas of high and mid latitude [28,31-35], and the few studies carried out on savannas biomes are located mainly in Africa and Australia [25,36-38]; furthermore, publications related to the effects of fire in Brazilian savanna are geographically and taxonomically biased [39].

Fire-related disturbances are common in Cerrado vegetation, where there is both the influence of natural fires that favor the maintenance of their structure, biodiversity and functioning [14], as well as the influence of anthropic fires with high capacity to modify surface patterns. Only recently, in protected areas of Cerrado, has there been established a policy of prescribed fires as a management strategy, with fire suppression policy being most used in the country for many decades $[14,40]$. The quantification of fire recurrence and its influence on different types of vegetation can help in the definition of ideal management strategies to each region, besides the possibility of evaluating the efficiency of each protected area in maintenance of the original structure of vegetation [14].

This study aimed to characterize the influence of fire recurrence on the phenological pattern of vegetation, in different phytophysiognomies in the largest conservation area of Brazilian savanna, the Jalapão, from time series of NDVI derived from Moderate Resolution Imaging Spectroradiometer (MODIS) sensor, and reconstruction of fire history in the region based on Landsat satellite images. 
I specifically seek (1) to characterize the fire recurrence in different phytophysiognomies present in the Jalapão area over a 16 years time series (2001-2016), from burn scars data derived from Landsat images; and (2) to quantify the phenological changes and its spatial variation in 16 years MODIS time-series NDVI related to fire recurrence and its conservation status by the application of a trend analysis on annual aggregated time series method (AAT).

\section{Materials and Methods}

\subsection{Study Area}

This study was conducted in the northeast portion of Brazilian Cerrado, in Jalapão region. The Jalapão is formed by a group of protected areas: Rio Preto Environmental Protection Area; Jalapão Environmental Protection Area; Serra da Tabatinga Environmental Protection Area; Rio Preto Ecological Station; Serra Geral do Tocantins Ecological Station; Jalapão State Park and Nascentes do Rio Parnaíba National Park, covering an area of about $28.000 \mathrm{~km}^{2}$, the largest conservation area of Brazilian Savanna [17] (Figure 1).

This area is composed of a variety of plant formations with different fire dependencies, being divided into the following groups: (a) savanna formations, or Cerrado, which vary according to density of tree and grass species, being forested savanna the one with more tree individuals and grassy-woody savanna with greater density of grasses; (b) seasonal forests, that have developed in more fertile soils being composed of original species from tropical forests; there are small areas of (c) steppe savannas, typical formations of semi-arid regions, where most species are deciduous and thorny, with a sparse ground cover; (d) pioneer vegetation in fluvial plains and (e) areas of secondary vegetation and agriculture [41].
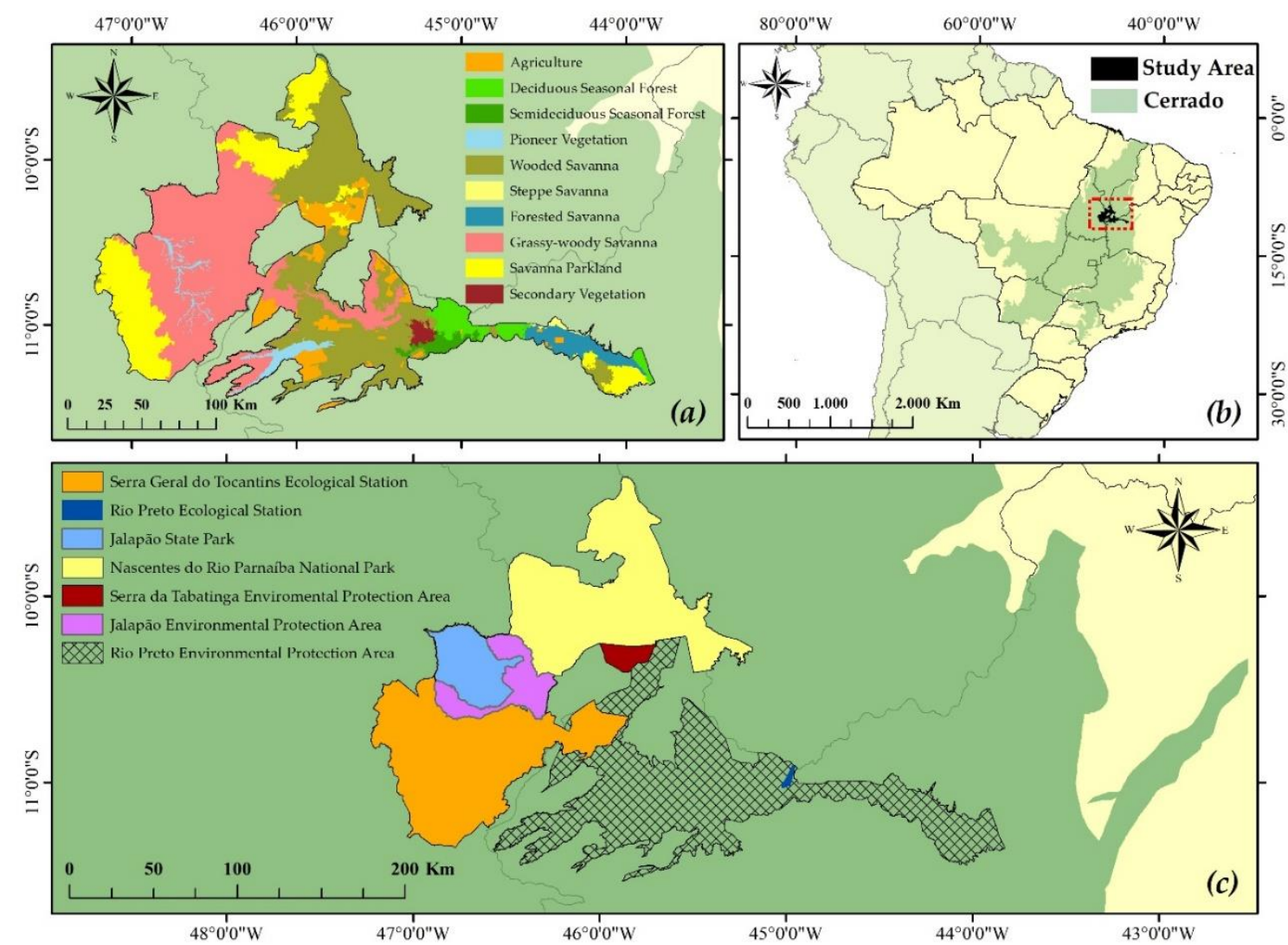

Figure 1. (a) Phytophysiognomies, (b) study area in the Brazilian Cerrado and (c) Jalapão set of protection areas. 
The study area is located in a tropical climate zone, with temperatures ranging from $22{ }^{\circ} \mathrm{C}$ to $27^{\circ} \mathrm{C}$, in two seasons, one wet, from October to March, with an average precipitation of more than $1500 \mathrm{~mm}$, and one dry season, from April to September [18]. The region is marked by sandy and nutrient-poor soils, which have limited the development of agriculture [42]; in its place, cattle ranching and sale of handcraft made from Syngonanthus nitens (Bong.) Ruhland (Eriocaulaceae), locally known as "golden grass", are the main economic activities [43]. Fire is largely used in cattle ranching and subsistence farming as a management tool, and to stimulate golden-grass flowering, much used in the region in craftsmanship of its floral stems [44,45]. The interaction between dry vegetation, high temperatures, and land-use management, results in out of control fires, reaching fire-sensitive areas like forests and wetlands [46].

\subsection{Fire Recurrence}

The Instituto Nacional de Pesquisas Espaciais (INPE) [47] dataset of burned areas, referring to Landsat images, was used to derive fire history in the study area, in the period 2001-2016; this dataset was acquired from INPE website (http:/ /www.inpe.br/queimadas/portal). All scenes and dates provided by INPE were complemented by visual interpretation of Landsat images, to improve the accuracy of burn scars mapping. The image dataset was composed of the last cloud-free Landsat Thematic Mapper (TM), Enhanced Thematic Mapper Plus (ETM+) and Operational Land Imager (OLI) image from the dry season, in years with a high presence of cloud cover; the closest date images were used among the three available sensors (Table 1). The Landsat dataset was acquired with geometric and atmospheric correction from the U.S. Geological Survey website (https: / / earthexplorer.usgs.gov/). In the year 2012, where there are only images derived from Landsat 7 and the INPE mapping was not performed, the MODIS MCD64A1 product [48] was used as a complement to ETM+ data, due to sensor failures after the year 2003 [49]. The image dataset from 2001 to 2016 was superimposed on INPE burn scars vector data, where burned areas omitted by INPE mapping method were inserted in the original data.

Table 1. Dataset used to complement the Instituto Nacional de Pesquisas Espaciais (INPE) mapping of burn scars, from 2001 to 2016, in Jalapão.

\begin{tabular}{cccc}
\hline Satellite & Sensor & Period Used & Total Scenes \\
\hline Landsat 5 & TM & $2001-2011$ & 11 \\
Landsat 7 & ETM+ & $2001-2003$ & 3 \\
Landsat 7 & ETM+ (SLC-off) & $2003-2016$ & 14 \\
Landsat 8 & OLI & $2013-2016$ & 4 \\
Terra and Aqua & MODIS (MCD64A1 product) & 2012 & 1 \\
\hline
\end{tabular}

\subsection{MODIS Time Series}

Among the remotely sensed vegetation indices, the NDVI is one of the most used to monitor vegetation dynamics, given its ability to measure canopy parameters, presenting a high correlation with estimates of biomass, leaf area and physiological functions [25,50,51]. Sixteen-days MODIS-NDVI composite images (MOD13Q1) were used to assess vegetation trend in Jalapão, in the period 2001-2016. The product MOD13Q1 returns pixels with the best visibility of the surface in a period of 16 days, with a spatial resolution of $250 \mathrm{~m}$ [52]. The dataset was acquired from National Aeronautics and Space Administration (NASA) Land Data Products and Services website (https://search.earthdata.nasa.gov/).

Time series derived from remote sensing are sensitive to atmospheric interference such as clouds and aerosols, or sensor failures. The Savitzky-Golay filter [53], available in Timesat software [54], was used to reduce noise interference. Besides being widely used in studies to denoise time series of vegetation indices [36,55-57], this filter is the one that best adapts in different types of surface, among those evaluated by Geng et al. [58]. This filter performs per pixel local polynomial regression to noise 
removal while retaining the waveform-peak [53], preserving natural seasonality or persistent changes in NDVI. It was used a window size of five to prevent loss of information related to fire. Figure 2 exemplifies the application of the Savitzky-Golay filter to a natural vegetation pixel.

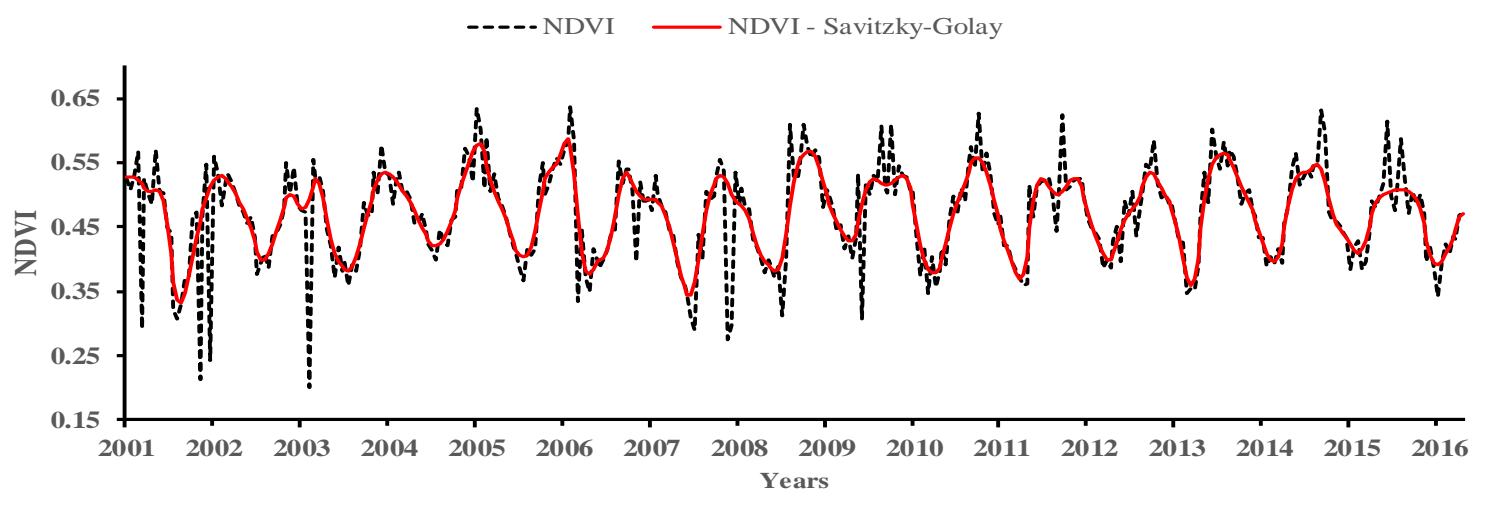

Figure 2. Noise reduction by application of Savitzky-Golay filter.

\subsection{Vegetation Trend Dynamics}

The NDVI time series was used in a trend analysis in the R environment software [59]. The package "greenbrown" (Land surface phenology and trend analysis) (http://greenbrown.r-forge.r-project. org /) [30] was used to determine the slope and direction of trend by an AAT. The "greenbrown" package encompasses several methods of analysis in remote sensing time series, with the trend analysis method, adapted by Forkel et al. [30], applied on a per pixel basis, considering the aggregation of entire time series in annual average data (mean annual NDVI). Mean annual NDVI data are evaluated in search of structural changes or breakpoints in a regression relationship based on the Bai and Perron method [60], requiring a minimum period of 48 months of data to define significant changes. Finally, the NDVI trend slopes are derived by linear least-squares regression and the significance of trend by the Mann-Kendall test $[61,62]$. The slopes values of trend indicate how much the NDVI will increase or decrease per year.

The mean slope and trend direction were estimated in different phytophysiognomies, derived from the biome-scale mapping carried out by the Brazil National Biodiversity Project (PROBIO) [63] and annual fire recurrence groups: (a) no burn; (b) Burned 2 times; (c) Burned 4 times; (d) Burned 6 times; (e) Burned 8 times; (f) Burned more than 8 times. In addition, the magnitude of changes was assessed according to the type of protection area in the region.

\section{Results}

\subsection{Fire Recurrence}

My determination of fire recurrence in Jalapão indicated that in the period between 2001 and 2016 , the fire affected an area of approximately $25,000 \mathrm{~km}^{2}$, corresponding to almost $89 \%$ of study area (Figure 3). More than $60 \%$ of the vegetation was burned at least three times, while unburned areas correspond to less than $10 \%$. The phytophysiognomies with the greatest fire occurrence were savanna and pioneer formations, in the western region of Jalapão. This area presents low fragmentation of vegetation and more than $90 \%$ of burned area. The lowest fire occurrence was observed in agricultural and forest areas, from the eastern Jalapão, that presented, respectively, less than $30 \%$ and $40 \%$ of the burned area, and corresponds to areas with the greatest vegetation fragmentation.

Fire events in different phytophysiognomies indicate clusters with similar recurrence (Figure 4): (a) Areas with low fire recurrence correspond to vegetation groups with the highest biomass, the deciduous forests, secondary vegetation, and forested savanna, in addition to areas of lower biomass, the steppe savanna. This group presented more than $40 \%$ of area unaffected by fire, and less than $30 \%$ 
were affected in only one year. (b) Similar to the previous clustering, agricultural areas show low fire recurrence, but most of the area was burned at least once. (c) Areas of high recurrence of fire were represented by savannas parkland, grassy-woody savannas and wooded savannas, as well as pioneer vegetation. These phytophysiognomies were burned on average 3 to 5 times in 16 years, and only $10 \%$ of the vegetation was not burned in the period.

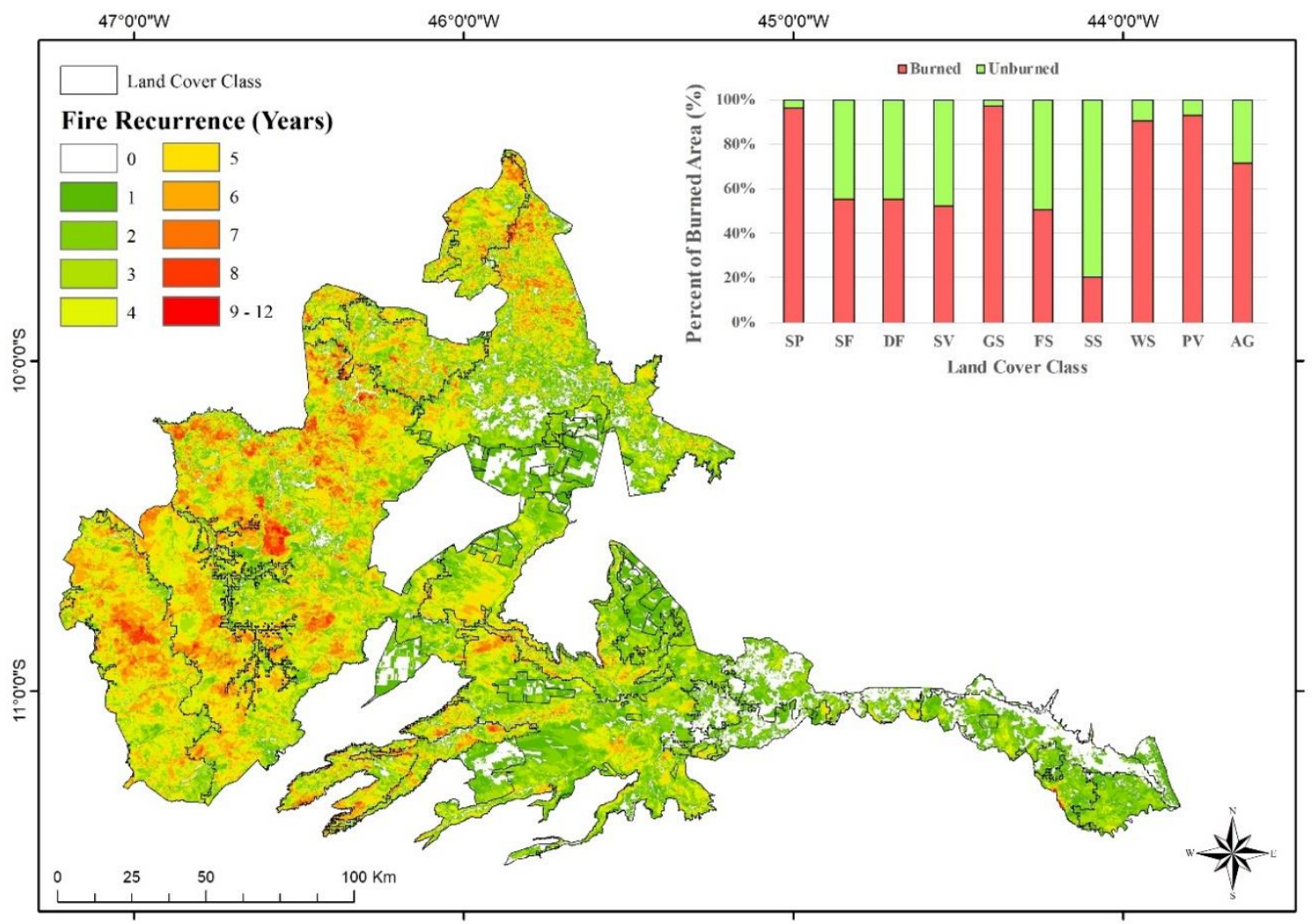

Figure 3. Fire recurrence map and percent of burned area in the different phytophysiognomies of Jalapão from 2001 to 2016. Key: Savanna Parkland (SP), Semideciduous Seasonal Forest (FS), Deciduous Seasonal Forest (DF), Secondary Vegetation (SV), Grassy-Woody Savanna (GS), Forested Savanna (FS), Steppe Savanna (SS), Wooded Savanna (WS), Pioneer Vegetation (PV) and Agriculture (AG).

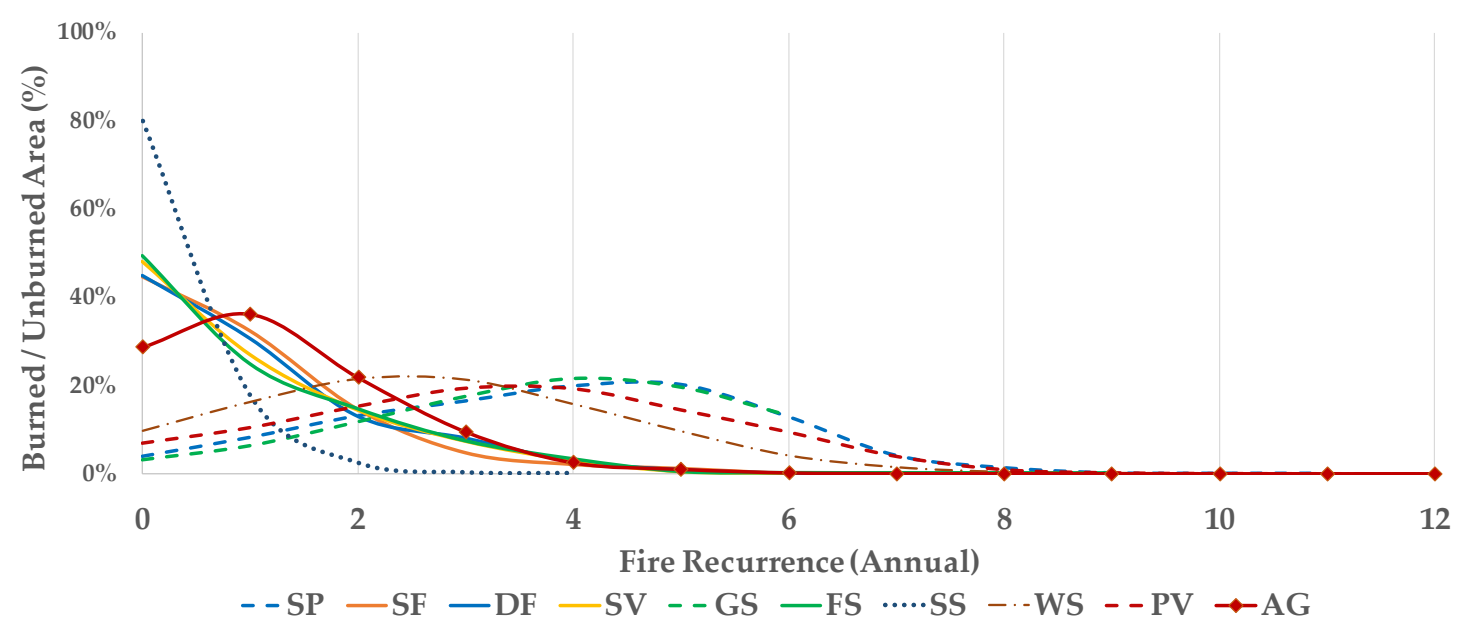

Figure 4. Percentage of burned area at different fire recurrences by group of vegetation. Key: Savanna Parkland (SP), Semideciduous Seasonal Forest (FS), Deciduous Seasonal Forest (DF), Secondary Vegetation (SV), Grassy-Woody Savanna (GS), Forested Savanna (FS), Steppe Savanna (SS), Wooded Savanna (WS), Pioneer Vegetation (PV) and Agriculture (AG). 


\subsection{Spatiotemporal Changes in Vegetation}

Based on the interannual trend analysis, different temporal patterns of vegetation were identified. Pixels with a significant slope of the NDVI trend $(p$-value $<0.05)$ either increasing or decreasing are highlighted in Figure 5. Positive slopes indicate an increase of up to 0.004 NDVI per year, while areas with negative slope indicate a decrease of up to -0.014 NDVI per year. Negative trend clusters are dominant in the center-east region of the study area, which is the area with greater anthropization, whereas positive clusters are mostly located in the central-north portion, an area with greater vegetation conservation.

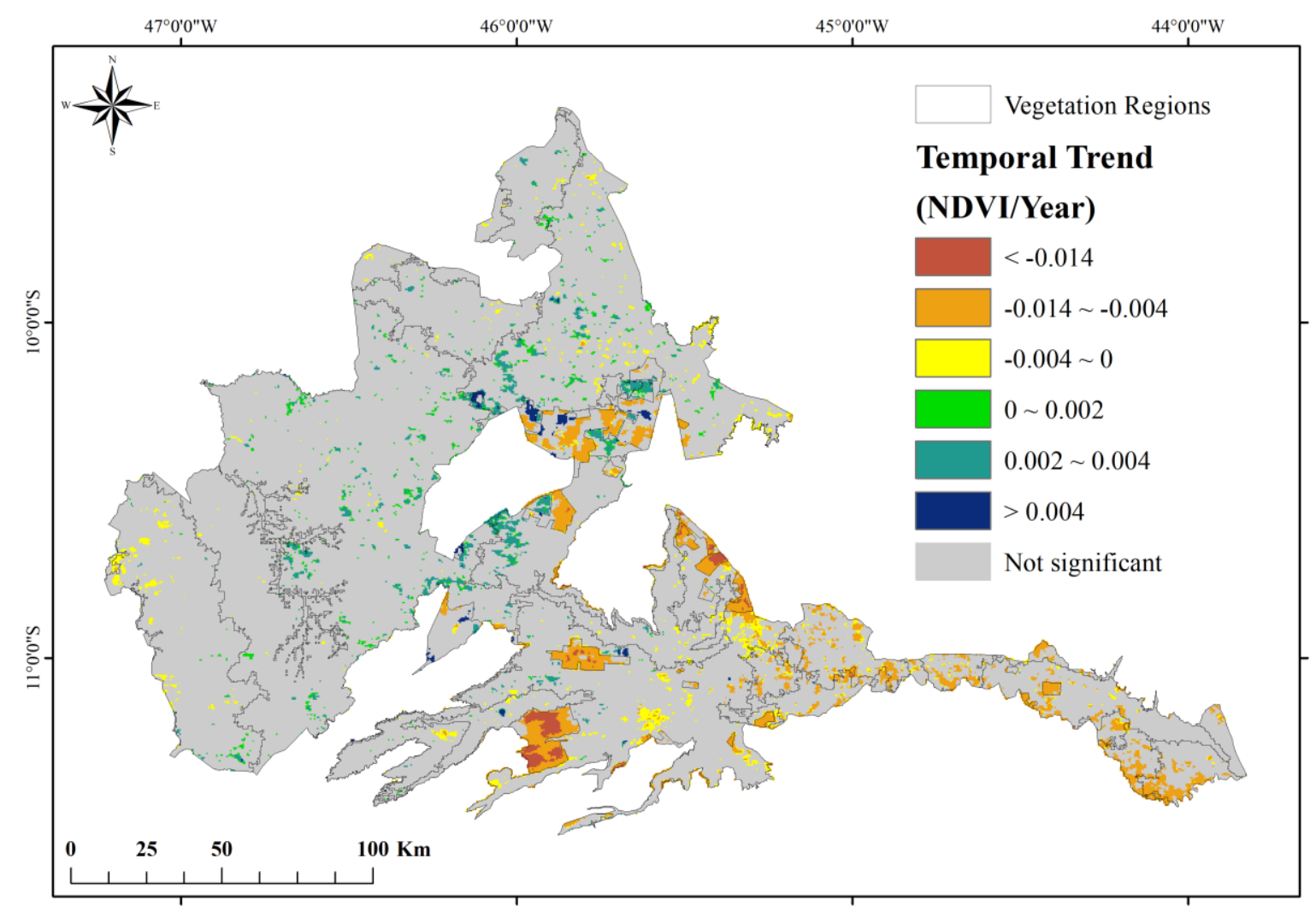

Figure 5. Distribution of statistically significant Normalized Difference Vegetation Index (NDVI) trends during the study period 2001-2016.

Figure 6 indicates that the spatial pattern of changes in NDVI is related to the status of vegetation protection. Full protection areas (Figure 1), including Serra Geral do Tocantins Ecological Station, Jalapão State Park and Nascentes do Rio Parnaíba National Park, presented more than $60 \%$ of areas with positive changes. Jalapão Environmental Protection Area, despite being a conservation unit for sustainable use, has low agricultural use, resulting in more than $90 \%$ of areas with positive changes. Rio Preto and Serra da Tabatinga Environmental Protection Areas, conservation units with high agricultural use, presented more than $70 \%$ of pixels with negative tendencies. Rio Preto Ecological Station, composed basically of deciduous seasonal forests, presented only negatively sloping pixels.

Figure 7 indicates that pioneer vegetation areas have a high capacity to maintain the positive temporal trend of NDVI in cases of low recurrence fires. There is an increment up to 0.002 of the average NDVI in areas where only one burn was detected, but the increase of fire recurrence caused a decline up to -0.002 of NDVI throughout the analyzed period. The vegetation converted into crops was the one with the greatest changes, with decreases up to 0.01 NDVI annually, being little related to the occurrence of fire. Deforestation causes a change in vegetation index response, resulting in negative 
trends where the NDVI of the crop is lower than that of the natural vegetation, or positive trends where the NDVI is higher (Figure 8).

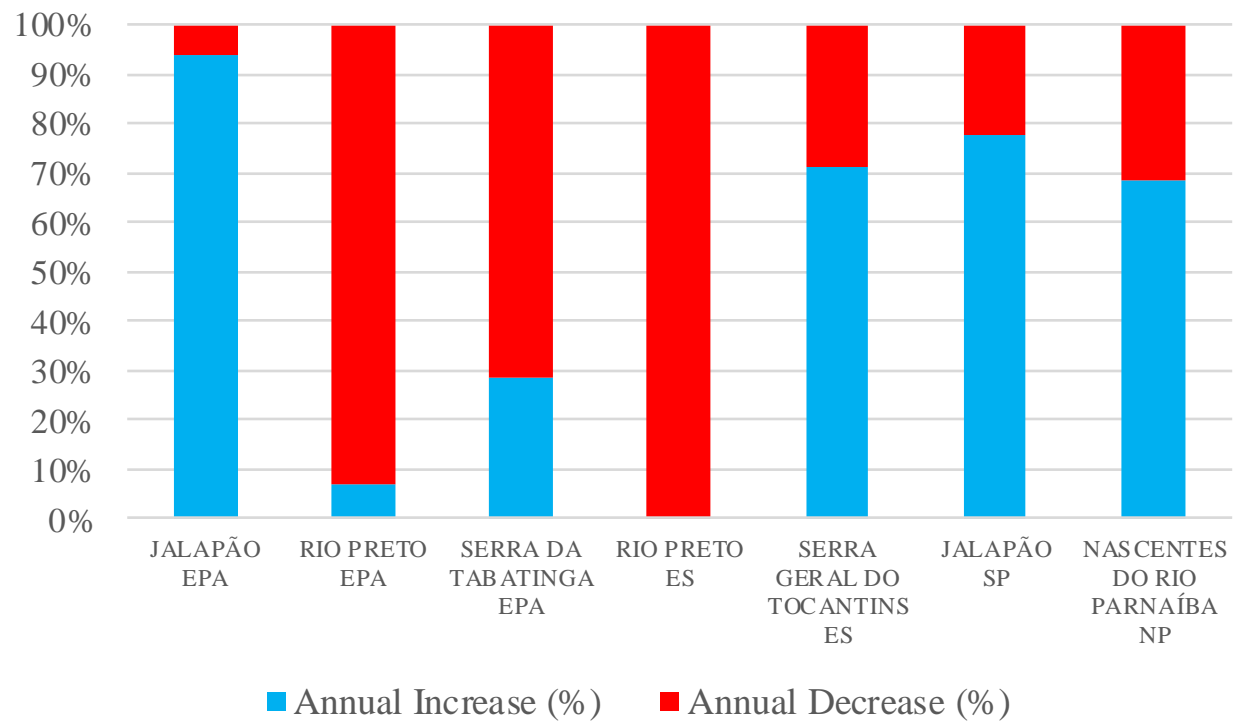

Figure 6. Direction of significant changes in different conservation units: Environmental Protection Area (EPA), Ecological Station (ES), State Park (SP) and National Park (NP).

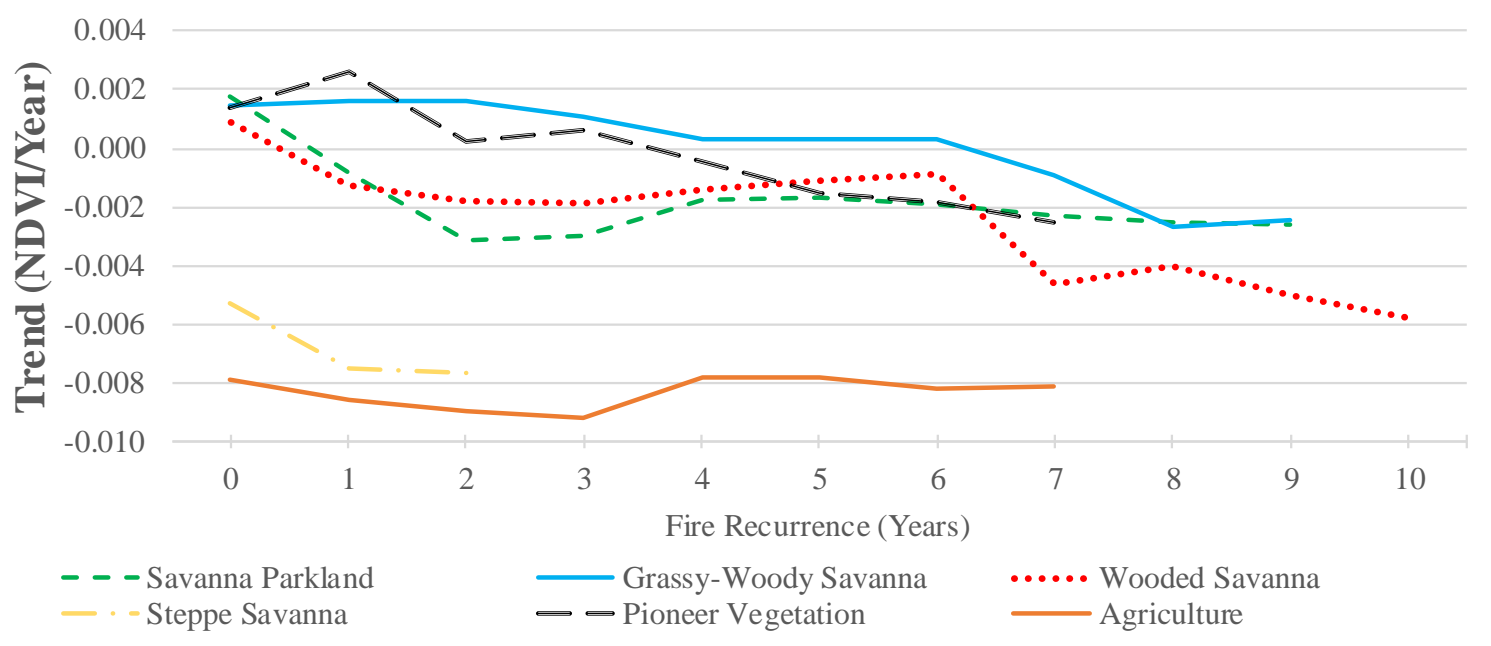

Figure 7. Average trend of savanna parkland, grassy-woody savanna, wooded savanna, steppe savanna, pioneer vegetation and agriculture exposed to different fire recurrences.

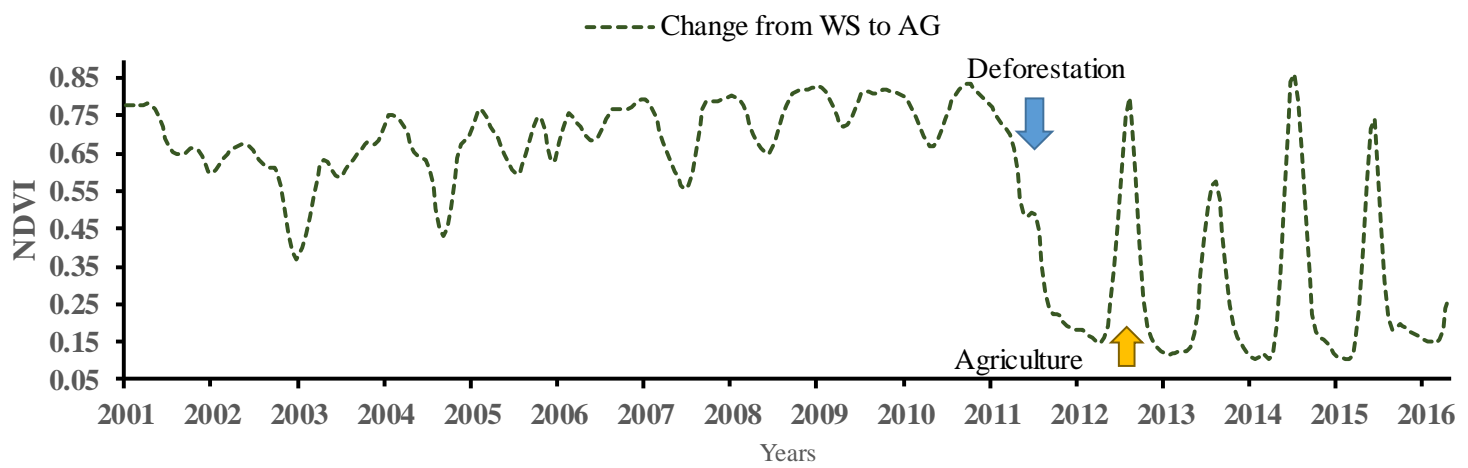

Figure 8. Example of NDVI time series highlighting the conversion of wooded savanna (WS) to agriculture (AG). 
Unburned pixels in areas of savanna parkland, grassy-woody savanna, and wooded savanna, presented a positive trend up to 0.001 annually, indicating an increase in vegetation activity with biomass growth, while areas with moderate fire recurrence showed a low vegetation index decrease. Savanna parkland and wooded savanna areas showed greater declines of NDVI in cases of low fire recurrence compared to grassy-woody savanna. However, in cases of high recurrence, in all savanna phytophysiognomies, there is a marked decrease in NDVI up to 0.008 (Figure 9). Steppe savanna, abundant in semi-arid zones, presented low fire recurrence, but observed significant NDVI declines in the whole area of this vegetation formation.

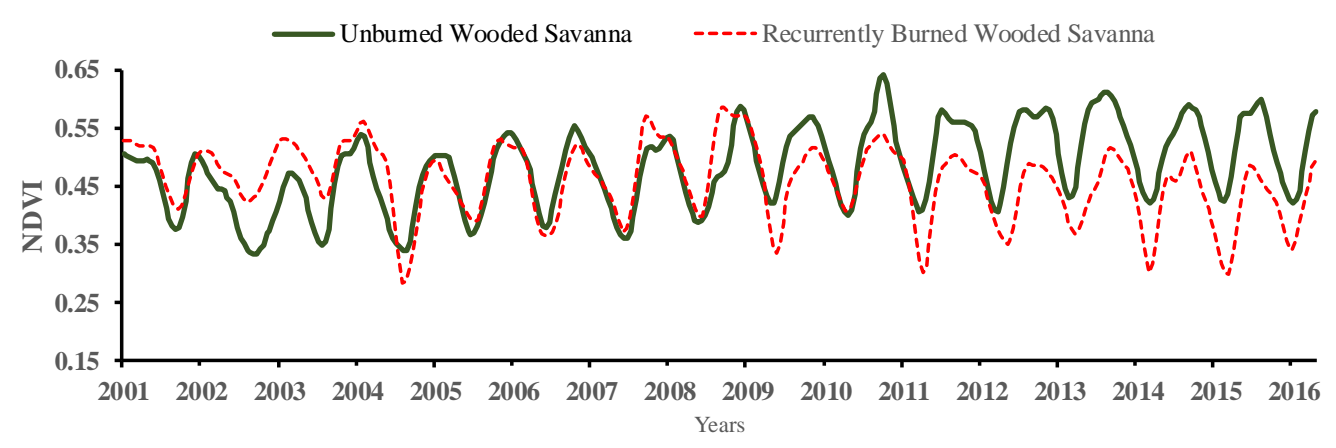

Figure 9. Example of NDVI time series of wooded savanna in two scenarios of fire recurrence.

Forest vegetation was the least affected by fires in Jalapão region (Figure 3); however, all the different forest physiognomies showed a high decrease of NDVI even in unburned areas (Figure 10). Only forested savannas and deciduous seasonal forests presented a significant decrease of up to 0.01 of annual NDVI in cases of high fire recurrence.

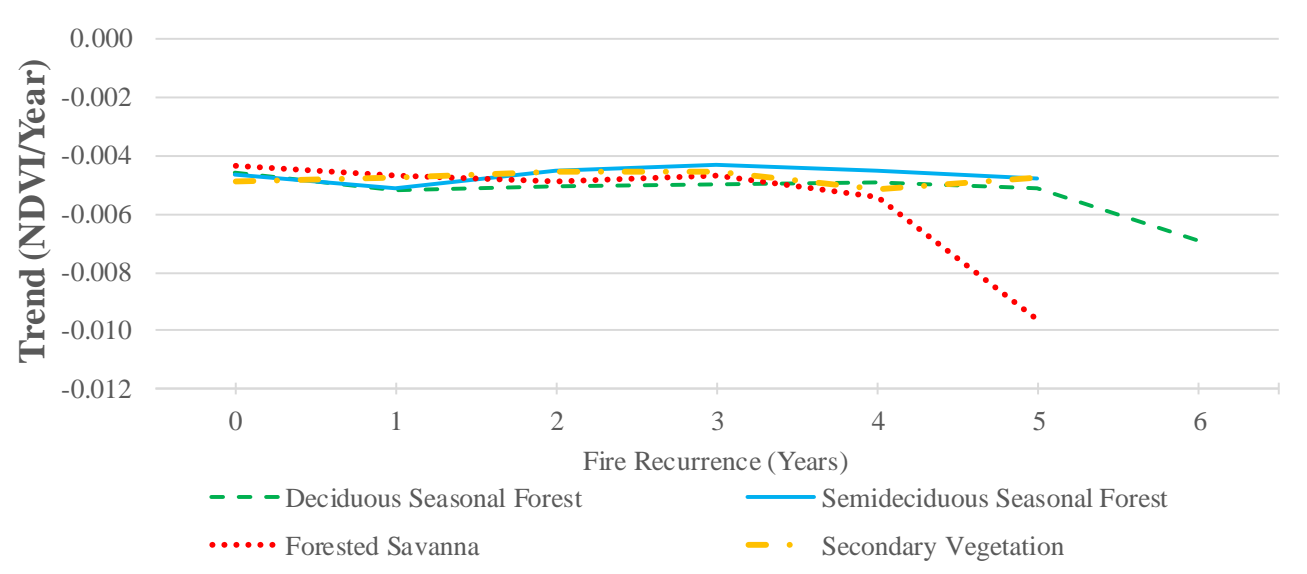

Figure 10. Average trend of deciduous seasonal forest, semideciduous seasonal forest, forested savanna and secondary vegetation exposed to different fire recurrences.

\section{Discussion}

\subsection{Spatial Patterns of Fire Recurrence}

My analysis indicates the high diversity of fire recurrence patterns in the different types of vegetation and conservation. The woody/grassy composition of Jalapão vegetation forms mosaics of savanna-forest that define the propensity of an area to be burned and at what recurrence. The type of area management is also a determining factor in the occurrence of fire including: (a) areas of severe land use restrictions, with low rates of vegetation fragmentation; (b) areas of restricted use, but handled by traditional communities; and (c) areas of low land use restriction, with intense agricultural use [44]. 
The pattern of fire in the Jalapão region is highly related to the type of phytophysiognomy and the management of area, either by the management of conservation units or by agricultural occupation. The observed fire recurrence, ranging from 1 to 12 occurrences in a same area in the 16 analyzed years, is similar to that presented previously by Hoffmann [9] in Brazilian savannas, with a minimum interval of 1.3 years for fire return. Forest formations, including seasonal forests, forested savanna and secondary vegetation, have a higher canopy cover and humidity than savanna areas, which limits the development of grasses species, resulting in slower propagation of fire [1,64]. Savanna formations, including wooded savanna, grassy-woody savanna and savanna parkland present high fire recurrence related mainly to availability of dry fuels, and its high spatial continuity that facilitate fire ignition and propagation $[65,66]$. As observed in other areas with transition from grass to forest, savanna areas of Jalapão have a higher burning rate than forest areas [66-68], as well as areas with greater fragmentation which are also those with smaller total burned areas [69].

Agricultural areas, with low total burnings, have a recurrence peak of only one year, indicating the possible use of fire as a tool to convert natural vegetation [70]. The steppe savannas, areas with lower availability of fuel in the region, are also those with less fire occurrence. This plant formation is common in semi-arid environments where low rainfall limits biomass growth [71], with consequent low spread potential [65]. Pioneer formations, here related to vegetation of first occupation in areas of fluvial influence, have a fire recurrence pattern similar to savannas; despite low representativity in the study area, they comprise zones of transition from savannas to wetlands, being able to burn with great recurrence [72].

It is important to highlight that the forest areas, related to Rio Preto Environmental Protection Area, despite having smaller burned areas, are highly influenced by human occupation, with high deforestation and conversion of these areas into agriculture and pasture. In the Jalapão region, the conversion of natural vegetation areas into agriculture is recent, being the last great agricultural frontier of Cerrado [73]. While the savanna areas, especially those in Serra Geral do Tocantins Ecological Station and Nascentes do Rio Parnaíba National Park, are the ones with the largest burned area, due to greater connectivity of vegetation and use of fire by traditional communities for "golden grass" cultivation $[45,46]$. Other parameters such as temperature, wind speed and the new practice of fire management by the park authorities are decisive for occurrence and dispersion of fire in areas of natural vegetation [14].

Fire has been one of the main phenomena in the present configuration of savanna vegetation, but was basically restricted to low severity fires from lightning strikes at the end of the wet season [74]. These low-severity fires have reduced the density and size of Cerrado woody species, allowing the growth of herbaceous species [9]. The development and expansion of agriculture and urban areas have led to a reduction of total area burned on global savannas [75]. Despite this, with more fragmented and degraded areas and invasion of exotic species, the number of small fires with high severity tends to increase $[74,76]$. The fire pattern in Jalapão region is consistent with studies conducted in African and Australian savannas, where the main determinants of fire occurrence are vegetation composition: tree, shrub or grass; and climate, where humid and semi-arid areas have fewer fires compared to semi-humid areas [77].

\subsection{Spatial Patterns of Vegetation Changes}

There are several models of trend detection from time series. Among those analyzed by Forkel et al. [30], the models using interannual variability are able to better distinguish change patterns compared to models that remove the annual cycle, and although it is more difficult to identify the exact periods of changes, these methods are less likely to identify false trends. NDVI time-series has been widely used to evaluate inter-annual variability of different types of vegetation [20,22,25,78-81]. Despite the ability to accurately indicate locations and periods of NDVI change, there are limitations on available methods, such as contamination of data series by noise, weather or climate change, and poor coverage of data for a same area. The application of methods such as the Savitzky-Golay filter and 
AAT analysis reduce the influence of noise in time series while emphasizing abrupt or phenological changes $[30,82]$. The high cloud cover in Jalapão during rainy season, combined with the smoke generated by fires in dry season, could influence trend analysis in the original data. Filters such as Savitzky-Golay could aid in reduction of anomalous data from analysis, besides not being influenced by different land covers because it is a technique applied on a per pixel basis.

Trend detection by the AAT method shows a decrease of NDVI with high fire recurrences in all types of vegetation, with each set of species being tolerant to a certain recurrence; it also shows an increase of NDVI in areas of fire exclusion in addition to areas with a decrease of NDVI not related to fire. Negative trends in the region may be associated with three main factors: (a) fire recurrence; (b) forest degradation, and (c) conversion of vegetation to agriculture or pasture. Agricultural areas are the main examples of changes not associated with fire, besides presenting the smallest trends in Jalapão. The trend analysis identified abrupt periods of changes related to vegetation conversion as shown in Figure 9. Despite this, it is expected that this trend will stabilize over the years, given the temporal persistence of NDVI in the same crop.

Positive trends are mainly related to a higher degree of vegetation protection and lower fire recurrence, due to greater accumulation of biomass and recruitment of species susceptible to fire [83-85]. Figure 10 exemplifies the time series of two wooded savanna areas; one of them was not burned and the other was burned with a high recurrence. In both scenarios, the presence or absence of fire is a determining factor in NDVI dynamics.

Although high fire recurrence causes the decrease of NDVI in most of the vegetation types analyzed, the main positive spatial changes are located in the western region of the study area, the one with the highest fire occurrence. Jalapão Environmental Protection Area which, despite being less restrictive in relation to land use, has low agricultural use, presents more than $90 \%$ of positive trends in areas with significant changes. The high agricultural use of Rio Preto and Serra da Tabatinga Environmental Protection Areas resulted in more than $70 \%$ of pixels with negative trends in areas with significant changes. Rio Preto Ecological Station, composed mainly of deciduous seasonal forests with low fire recurrence, presented only negative slope trends, indicating that forest degradation is more important than fire in determining the trend of forest vegetation.

The efficiency of protected areas in reduction of forest fires was analyzed, for example, in the global tropical forests by Nelson and Chomitz [86], and by Welch et al. [87] in an indigenous land in Brazilian savanna. The authors indicate that multiple use protected areas and indigenous lands are the main forms of fire prevention, since traditional management practices can be used, reducing total ignition. The protected areas of Jalapão have similar patterns of fire occurrence as reported in other studies, especially the scenario described by Archibald [74] for Africa: large areas of protected vegetation in African savannas are the main ones in terms of burned area, but the number of small and with high severity fires are higher in areas with greater anthropization and fragmentation. High severity fires, along with deforestation, are responsible for increasing forest degradation in multiple use conservation areas, such as environmental protection areas, leading to a negative NDVI trend, despite having a smaller burned area.

The effects of fire on forest vegetation mainly lead to reduction of woody species, given its negative effect on establishment of tree and shrub seedlings. High recurrence fires favor the development of grass species, which may result in transformation of the forest into savanna [15]. In contradiction, the trend analysis indicates that even non-burned areas showed a decrease of NDVI in the last 15 years. Other effects such as forest degradation, climate change and introduction of exotic species may explain the decrease of non-fire vegetation [18].

\subsection{Management Implications}

As previously indicated by several authors $[14,15,44,69]$, the results presented in this study reinforce the need for a consistent fire management policy in the Brazilian Cerrado. A new fire management policy has been implemented in Jalapão conservation units, with the aim of protecting 
forest and sensitive areas by creating mosaics of low intensity burned areas, with different stages of regeneration [40]. This strategy is similar to that used by indigenous communities, where mosaics of burned areas are created at the beginning of the dry season to prevent high-severity fires. These traditional techniques are proven to be some of the most sustainable for long-term maintenance of Cerrado vegetation $[87,88]$.

Fire exclusion in savanna areas leads to an increase in NDVI, making vegetation more susceptible to new fires by the establishment of fire-sensitive tree species [15], while the high fire recurrence also causes severe damage to the vegetation structure, especially in forest formations. From the identification of NDVI temporal trends due to different fire recurrence scenarios, it is possible to define specific fire management parameters for each type of phytophysiognomy, besides allowing its spatial monitoring.

In addition, the methodology allowed to evaluate the vegetation conditions in different protected areas, which may help to quantify the degradation of each unit and establish conservation strategies in units without management plans or even in the revision of existing practices. In Brazil, the environmental protection areas, such as the Rio Preto and Serra da Tabatinga, are conservation units with low land use restrictions, being composed by both public and private lands, resulting in high rates of deforestation and vegetation degradation. Contrarily, ecological stations such as Serra Geral do Tocantins are the most restrictive ones, being forbidden, for example, to public visitations. Besides these different restrictions, fire is widely used by local populations in these area, and rescuing management techniques such as those applied by indigenous communities in management of vegetation and fire are some of the most suitable for conservation [86].

Despite these observations, some limitations of the work include the low spatial resolution of the sensor used, 250 meters in the case of MODIS, which leads to a high spectral mixing of targets on the surface and can influence the results in small vegetation fragments; there is also the time series of 16 years, which is not large enough to confirm long-term changes.

\section{Conclusions}

This study aimed to evaluate the influence of fire recurrence on the phenology of Brazilian Cerrado in Jalapão region. With the reconstruction of fire history in the region based on data from Landsat imagery, and trend analysis in NDVI time series of MODIS sensor, I verified the uniqueness of the type of vegetation in relation to its degree of conservation and fire regime.

The Jalapão region consists of a mosaic of integral and sustainable use conservation units. The conservation of vegetation is the main determinant factor in positive and negative tendency of NDVI, while fire is another important agent. Forest areas, despite having a lower fire recurrence, are the natural phytophysiognomies with the highest decrease in NDVI, indicating that these areas are highly degraded, although they are located in conservation units. The Serra da Tabatinga and Rio Preto Environmental Protection Areas do not have major land use restrictions, besides not having long-term management plans for vegetation and fire, resulting in more than $70 \%$ of areas with significant negatives trends. This fact reinforces the need for creation of long-term policies for maintenance of current forest structure.

Finally, the savanna physiognomies have basically three stages of relation with fire: (a) areas with fire protection tend to increase NDVI, due to high accumulation of biomass and increase of tree species; (b) areas with low and moderate fire recurrence present the maintenance of current structure of vegetation, due to low mortality of species adapted to fire; (c) areas with high fire recurrence present an intense decrease of vegetation, indicating that even species with higher resistance to fire have a recurrence limit at which the NDVI begins to decay. The use of this methodology provides details of the influence of landscape changes on vegetation dynamics, especially with a view to defining optimal management practices for each type of vegetation, although it requires a longer time series to validate the phenological changes of vegetation. Future studies should evaluate other methods of 
trend estimates in longer time series and with sensors of greater spatial resolution to compare with the results observed in this study.

Funding: This research received no external funding.

Acknowledgments: The author thanks the Coordination for the Improvement of Higher Education Personnel (CAPES) for the scholarship granted and NASA/USGS/INPE for the free distribution of datasets.

Conflicts of Interest: The author declare no conflict of interest.

\section{References}

1. Bowman, D.M.J.S.; Balch, J.; Artaxo, P.; Bond, W.J.; Cochrane, M.A.; D’Antonio, C.M.; Defries, R.; Johnston, F.H.; Keeley, J.E.; Krawchuk, M.A.; et al. The human dimension of fire regimes on Earth. J. Biogeogr. 2011, 38, 2223-2236. [CrossRef] [PubMed]

2. Archibald, S.; Lehmann, C.E.R.; Belcher, C.M.; Bond, W.J;; Bradstock, R.A.; Daniau, A.L.; Dexter, K.G.; Forrestel, E.J.; Greve, M.; He, T.; et al. Biological and geophysical feedbacks with fire in the Earth system. Environ. Res. Lett. 2018, 13. [CrossRef]

3. Murphy, B.P.; Bowman, D.M.J.S. What controls the distribution of tropical forest and savanna? Ecol. Lett. 2012, 15, 748-758. [CrossRef] [PubMed]

4. Bond, W.J.; Woodward, F.I.; Midgley, G.F. The Global Distribtuion of Ecosystems in a world without Fire. New Phytol. 2005, 165, 525-538. [CrossRef] [PubMed]

5. Pausas, J.G.; Ribeiro, E. Fire and plant diversity at the global scale. Glob. Ecol. Biogeogr. 2017, 26, 889-897. [CrossRef]

6. Oluwole, F.A.; Sambo, J.M.; Sikhalazo, D. Long-term effects of different burning frequencies on the dry savannah grassland in South Africa. African J. Agric. Res. 2008, 3, 147-153.

7. Uys, R.G.; Bond, W.J.; Everson, T.M. The effect of different fire regimes on plant diversity in southern African grasslands. Biol. Conserv. 2004, 118, 489-499. [CrossRef]

8. Williams, R.J.; Cook, G.D.; Gill, A.M.; Moore, P.H.R. Fire regime, fire intensity and tree survival in a tropical savanna in northern Australia. Austral Ecol. 1999, 24, 50-59. [CrossRef]

9. Hoffmann, W.A. Fire and Population Dynamics of Woody Plants in a Neotropical Savanna: Matrix Model Projections. Ecology 1999, 80, 1354. [CrossRef]

10. Schwieder, M.; Leitão, P.J.; da Cunha Bustamante, M.M.; Ferreira, L.G.; Rabe, A.; Hostert, P. Mapping Brazilian savanna vegetation gradients with Landsat time series. Int. J. Appl. Earth Obs. Geoinf. 2016, 52, 361-370. [CrossRef]

11. De Dantas, V.L.; Batalha, M.A.; Pausas, J.G. Fire drives functional thresholds on the savanna - forest transition. Ecology 2013, 94, 2454-2463. [CrossRef]

12. Coutinho, L.M. Ecological Effects of Fire in Brazilian Cerrado. In Ecology of Tropical Savannas; Huntley, B.J., Walker, B.H., Eds.; Springer: Berlin/Heidelberg, Germany, 1982; pp. 273-291.

13. Medeiros, M.B.; Miranda, H.S. Post-fire resprouting and mortality in Cerrado woody plant species over a three-year period. Edinburgh J. Bot. 2008, 65, 53-68. [CrossRef]

14. Durigan, G.; Ratter, J.A. The need for a consistent fire policy for Cerrado conservation. J. Appl. Ecol. 2016, 53, 11-15. [CrossRef]

15. Moreira, A.G. Effects of fire protection on savanna structure in central Brazil. J. Biogeogr. 2000, 27, 1021-1029. [CrossRef]

16. De Oliveira, S.N.; de Carvalho Júnior, O.A.; Gomes, R.A.T.; Guimarães, R.F.; McManus, C.M. Landscape-fragmentation change due to recent agricultural expansion in the Brazilian Savanna, Western Bahia, Brazil. Reg. Environ. Chang. 2017, 17, 411-423. [CrossRef]

17. Da Silva, J.M.C.; Bates, J.M. Biogeographic Patterns and Conservation in the South American Cerrado: A Tropical Savanna Hotspot. Bioscience 2002, 52, 225-233. [CrossRef]

18. Klink, C.A.; Machado, R.B. Conservation of the Brazilian Cerrado. Conserv. Biol. 2005, 19, 707-713. [CrossRef]

19. Hoffmann, W.A.; Schroeder, W.; Jackson, R.B. Positive feedbacks of fire, climate, and vegetation and the conversion of tropical savanna. Geophys. Res. Lett. 2002, 29, 9-1-9-4. [CrossRef]

20. Vrieling, A.; De Leeuw, J.; Said, M.Y. Length of growing period over africa: Variability and trends from 30 years of NDVI time series. Remote Sens. 2013, 5, 982-1000. [CrossRef] 
21. Butt, B.; Turner, M.D.; Singh, A.; Brottem, L. Use of MODIS NDVI to evaluate changing latitudinal gradients of rangeland phenology in Sudano-Sahelian West Africa. Remote Sens. Environ. 2011, 115, 3367-3376. [CrossRef]

22. Silva, F.B.; Shimabukuro, Y.E.; Aragão, L.E.O.C.; Anderson, L.O.; Pereira, G.; da Cardozo, F.S.; Arai, E. Large-scale heterogeneity of Amazonian phenology revealed from 26-year long AVHRR/NDVI time-series. Environ. Res. Lett. 2013, 8, 12. [CrossRef]

23. Anderson, L.O.; Malhi, Y.; Aragão, L.E.O.C.; Ladle, R.; Arai, E.; Barbier, N.; Phillips, O. Remote sensing detection of droughts in Amazonian forest canopies. New Phytol. 2010, 187, 733-750. [CrossRef] [PubMed]

24. Koltunov, A.; Ustin, S.L.; Asner, G.P.; Fung, I. Selective logging changes forest phenology in the Brazilian Amazon: Evidence from MODIS image time series analysis. Remote Sens. Environ. 2009, 113, 2431-2440. [CrossRef]

25. Zewdie, W.; Csaplovics, E.; Inostroza, L. Monitoring ecosystem dynamics in northwestern Ethiopia using NDVI and climate variables to assess long term trends in dryland vegetation variability. Appl. Geogr. 2017, 79, 167-178. [CrossRef]

26. Fernandez-Manso, A.; Quintano, C.; Roberts, D.A. Burn severity influence on post-fire vegetation cover resilience from Landsat MESMA fraction images time series in Mediterranean forest ecosystems. Remote Sens. Environ. 2016, 184, 112-123. [CrossRef]

27. Caccamo, G.; Bradstock, R.A.; Collins, L.; Penman, T.D.; Watson, P. Using MODIS data to analyse post-fire vegetation recovery in Australian eucalypt forests. J. Spat. Sci. 2014, 8596, 1-12. [CrossRef]

28. Van Leeuwen, W.J.D.; Casady, G.M.; Neary, D.G.; Bautista, S.; Alloza, J.A.; Carmel, Y.; Wittenberg, L.; Malkinson, D.; Orr, B.J. Monitoring post-wildfire vegetation response with remotely sensed time-series data in Spain, USA and Israel. Int. J. Wildl. Fire 2010, 19, 75-93. [CrossRef]

29. Corner, B.R.; Narayanan, R.M.; Reichenbach, S.E. Noise estimation in remote sensing imagery using data masking. Int. J. Remote Sens. 2003, 24, 689-702. [CrossRef]

30. Forkel, M.; Carvalhais, N.; Verbesselt, J.; Mahecha, M.D.; Neigh, C.S.R.; Reichstein, M. Trend Change detection in NDVI time series: Effects of inter-annual variability and methodology. Remote Sens. 2013, 5, 2113-2144. [CrossRef]

31. Katagis, T.; Gitas, I.Z.; Toukiloglou, P.; Veraverbeke, S.; Goossens, R. Trend analysis of medium- and coarse-resolution time series image data for burned area mapping in a Mediterranean ecosystem. Int. J. Wildl. Fire 2014, 23, 668-677. [CrossRef]

32. Clemente, R.H.; Navarro Cerrillo, R.M.; Gitas, I.Z. Monitoring post-fire regeneration in Mediterranean ecosystems by employing multitemporal satellite imagery. Int. J. Wildl. Fire 2009, 18, 648-658. [CrossRef]

33. Van Leeuwen, W.J.D. Monitoring the Effects of Forest Restoration Treatments on Post-Fire Vegetation Recovery with MODIS Multitemporal Data. Sensors 2008, 8, 2017-2042. [CrossRef] [PubMed]

34. Polychronaki, A.; Gitas, I.Z.; Minchella, A. Monitoring post-fire vegetation recovery in the Mediterranean using SPOT and ERS imagery. Int. J. Wildl. Fire 2014, 23, 631-642. [CrossRef]

35. Chen, X.; Vogelmann, J.E.; Rollins, M.; Ohlen, D.; Key, C.H.; Yang, L.; Huang, C.; Shi, H. Detecting post-fire burn severity and vegetation recovery using multitemporal remote sensing spectral indices and field-collected composite burn index data in a ponderosa pine forest. Int. J. Remote Sens. 2011, 32, 7905-7927. [CrossRef]

36. Mishra, N.B.; Crews, K.A.; Neeti, N.; Meyer, T.; Young, K.R. MODIS derived vegetation greenness trends in African Savanna: Deconstructing and localizing the role of changing moisture availability, fire regime and anthropogenic impact. Remote Sens. Environ. 2015, 169, 192-204. [CrossRef]

37. Jacquin, A.; Sheeren, D.; Lacombe, J.P. Vegetation cover degradation assessment in Madagascar savanna based on trend analysis of MODIS NDVI time series. Int. J. Appl. Earth Obs. Geoinf. 2010, 12, 3-10. [CrossRef]

38. Schmidt, M.; Lucas, R.; Bunting, P.; Verbesselt, J.; Armston, J. Multi-resolution time series imagery for forest disturbance and regrowth monitoring in Queensland, Australia. Remote Sens. Environ. 2015, 158, 156-168. [CrossRef]

39. De Arruda, F.V.; De Sousa, D.G.; Teresa, F.B.; do Prado, V.H.M.; da Cunha, H.F.; Izzo, T.J. Trends and gaps of the scientific literature about the effects of fire on Brazilian Cerrado. Biota Neotrop. 2018, 18, 1-6. [CrossRef]

40. Schmidt, I.S.; Fonseca, C.B.; Ferreira, M.C.; Sato, M.N. Implementação do Programa Piloto de Manejo Integrado do Fogo em três Unidades de Conservação do Cerrado. Biodiversidade Bras. 2016, 6, 55-70. 
41. Instituto Brasileiro de Geografia e Estatística (IBGE). Manual Técnico da Vegetação Brasileira; Instituto Brasileiro de Geografia e Estatística-IBGE: Rio de Janeiro, Brazil, 2012.

42. De Santana, H.M.P.; Sano, E.E.; de Júniorde, M.P.O.; Lacerda, M.P.C.; Malaquias, J.V. Relação entre atributos físicos e químicos dos solos e a produtividade de capim dourado na Região do Jalapão, TO. Rev. Bras. Cienc. do Solo 2015, 39, 1172-1180. [CrossRef]

43. Schmidt, I.B.; Figueiredo, I.B.; Borghetti, F.; Scariot, A. Produção e germinação de sementes de "capim dourado", Syngonanthus nitens (Bong.) Ruhland (Eriocaulaceae): Implicações para o manejo. Acta Bot. Brasilica 2008, 22, 37-42. [CrossRef]

44. Pereira Júnior, A.C.; Oliveira, S.L.J.; Pereira, J.M.C.; Turkman, M.A.A. Modelling fire frequency in a Cerrado savanna protected area. PLoS ONE 2014, 9. [CrossRef] [PubMed]

45. Borges, S.L.; Eloy, L.; Schmidt, I.B.; Barradas, A.C.S.; Santons, I.A. dos Manejo do Fogo em Veredas: Novas perspectivas a partir dos sistemas agrícolas tradicionais no Jalapão. Ambient. Soc. 2016, 19, $269-294$. [CrossRef]

46. Schmidt, I.B.; Sampaio, M.B.; Figueiredo, I.B.; Ticktin, T. Fogo e Artesanato de Capim-dourado no Jalapão: Usos Tradicionais e Consequências Ecológicas. Biodiversidade Bras. 2011, 1, 67-85.

47. Instituto Nacional de Pesquisas Espaciais (INPE). Portal do Monitoramento de Queimadas e Incêndios. Available online: http:/ / www.inpe.br/queimadas (accessed on 22 June 2015).

48. Giglio, L.; Loboda, T.; Roy, D.P.; Quayle, B.; Justice, C.O. An active-fire based burned area mapping algorithm for the MODIS sensor. Remote Sens. Environ. 2009, 113, 408-420. [CrossRef]

49. Arvidson, T.; Goward, S.N.; Gasch, J.; Williams, D. Landsat-7 long-term acquisition plan: Development and validation. Photogramm. Eng. Remote Sensing 2006, 72, 1137-1146. [CrossRef]

50. Myneni, R.B.; Hall, F.G.; Sellers, P.J.; Marshak, A.L. The interpretation of spectral vegetation indexes. IEEE Trans. Geosci. Remote Sens. 1995, 33, 481-486. [CrossRef]

51. Anderson, L.O. Biome-scale forest properties in Amazonia based on field and satellite observations. Remote Sens. 2012, 4, 1245-1271. [CrossRef]

52. Justice, C.O.; Townshend, J.R.G.; Vermote, E.F.; Masuoka, E.; Wolfe, R.E.; Saleous, N.; Roy, D.P.; Morisette, J.T. An overview of MODIS Land data processing and product status. Remote Sens. Environ. 2002, 83, 3-15. [CrossRef]

53. Savitzky, A.; Golay, M.J.E. Smoothing and Differentiation of Data by Simplified Least Squares Procedures. Anal. Chem. 1964, 36, 1627-1639. [CrossRef]

54. Jönsson, P.; Eklundh, L. TIMESAT-A program for analyzing time-series of satellite sensor data. Comput. Geosci. 2004, 30, 833-845. [CrossRef]

55. Chen, J.; Jönsson, P.; Tamura, M.; Gu, Z.; Matsushita, B.; Eklundh, L. A simple method for reconstructing a high-quality NDVI time-series data set based on the Savitzky-Golay filter. Remote Sens. Environ. 2004, 91, 332-344. [CrossRef]

56. Abade, N.A.; de Carvalho Júnior, O.A.; Guimarães, R.F.; Oliveira, S.N. De Comparative Analysis of MODIS Time-Series Classification Using Support Vector Machines and Methods Based upon Distance and Similarity Measures in the Brazilian Cerrado-Caatinga Boundary. Remote Sens. 2015, 7, 12160-12191. [CrossRef]

57. De Carvalho Júnior, O.A.; Guimarães, R.F.; Silva, C.; Gomes, R.A.T. Standardized Time-Series and Interannual Phenological Deviation: New Techniques for Burned-Area Detection Using Long-Term MODIS-NBR Dataset. Remote Sens. 2015, 7, 6950-6985. [CrossRef]

58. Geng, L.; Ma, M.; Wang, X.; Yu, W.; Jia, S.; Wang, H. Comparison of Eight Techniques for Reconstructing Multi-Satellite Sensor Time-Series NDVI Data Sets in the Heihe River Basin, China. Remote Sens. 2014, 6, 2024-2049. [CrossRef]

59. R Core Team. R: A Language and Environment for Statistical Computing; R Foundation for Statistical Computing: Viena, Austria, 2014.

60. Bai, J.; Perron, P. Computation and analysis of multiple structural change models. J. Appl. Econom. 2003, 18, 1-22. [CrossRef]

61. Mann, H.B. Nonparametric Tests Against Trend. Econometrica 1945, 13, 245. [CrossRef]

62. Kendall, M.G. Rank correlation methods, 2nd ed.; Hafner Publishing Co.: Oxford, UK, 1955.

63. Ministério do Meio Ambiente (MMA). Mapeamento da Cobertura Vegetal do Bioma Cerrado, Edital Probio 02/2004, Projeto Executivo B.02.02.109, Relatório Final. Available online: http://mapas.mma.gov.br/ (accessed on 22 February 2018). 
64. Hoffmann, W.A.; Geiger, E.L.; Gotsch, S.G.; Rossatto, D.R.; Silva, L.C.R.; Lau, O.L.; Haridasan, M.; Franco, A.C. Ecological thresholds at the savanna-forest boundary: How plant traits, resources and fire govern the distribution of tropical biomes. Ecol. Lett. 2012, 15, 759-768. [CrossRef]

65. Bradstock, R.A. A biogeographic model of fire regimes in Australia: Current and future implications. Glob. Ecol. Biogeogr. 2010, 19, 145-158. [CrossRef]

66. Alves, D.B.; Pérez-Cabello, F. Multiple remote sensing data sources to assess spatio-temporal patterns of fire incidence over Campos Amazônicos Savanna Vegetation Enclave (Brazilian Amazon). Sci. Total Environ. 2017, 601-602, 142-158. [CrossRef] [PubMed]

67. Oliveira, S.L.J.; Turkman, M.A.A.; Pereira, J.M.C. An analysis of fire frequency in tropical savannas of northern Australia, using a satellite-based fire atlas. Int. J. Wildl. Fire 2013, 22, 479-492. [CrossRef]

68. Daldegan, G.A.; de Carvalho Júnior, O.A.; Guimarães, R.F.; Gomes, R.A.T.; Ribeiro, F.D.F.; McManus, C. Spatial patterns of fire recurrence using remote sensing and GIS in the Brazilian savanna: Serra do Tombador Nature Reserve, Brazil. Remote Sens. 2014, 6, 9873-9894. [CrossRef]

69. Alvarado, S.T.; Silva, T.S.F.; Archibald, S. Management impacts on fire occurrence: A comparison of fire regimes of African and South American tropical savannas in different protected areas. J. Environ. Manage. 2018, 218, 79-87. [CrossRef] [PubMed]

70. Pivello, V.R. The use of fire in the cerrado and Amazonian rainforests of Brazil: Past and present. Fire Ecol. 2011, 7, 24-39. [CrossRef]

71. Marlon, J.R.; Bartlein, P.J.; Daniau, A.L.; Harrison, S.P.; Maezumi, S.Y.; Power, M.J.; Tinner, W.; Vanniére, B. Global biomass burning: A synthesis and review of Holocene paleofire records and their controls. Quat. Sci. Rev. 2013, 65, 5-25. [CrossRef]

72. Guiomar, N.; Godinho, S.; Fernandes, P.M.; Machado, R.; Neves, N.; Fernandes, J.P. Wildfire patterns and landscape changes in Mediterranean oak woodlands. Sci. Total Environ. 2015, 536, 338-352. [CrossRef] [PubMed]

73. Bragança, A.A. The Causes and Consequences of Agricultural Expansion in Matopiba. Rev. Bras. Econ. 2018, 72, 161-185. [CrossRef]

74. Archibald, S. Managing the human component of fire regimes: Lessons from Africa. Philos. Trans. R. Soc. B Biol. Sci. 2016, 371, 20150346. [CrossRef]

75. Andela, N.; Morton, D.C.; Giglio, L.; Chen, Y.; van der Werf, G.R.; Kasibhatla, P.S.; DeFries, R.S.; Collatz, G.J.; Hantson, S.; Kloster, S.; et al. A human-driven decline in global burned area. Science 2017, 356, 1356-1362. [CrossRef]

76. Rossiter, N.A.; Setterfield, S.A.; Douglas, M.M.; Hutley, L.B. Testing the grass-fire cycle: Alien grass invasion in the tropical savannas of northern Australia. Divers. Distrib. 2003, 9, 169-176. [CrossRef]

77. Felderhof, L.; Gillieson, D. Comparison of fire patterns and fire frequency in two tropical savanna bioregions. Austral Ecol. 2006, 31, 736-746. [CrossRef]

78. Schucknecht, A.; Erasmi, S.; Niemeyer, I.; Matschullat, J. Assessing vegetation variability and trends in north-eastern Brazil using AVHRR and MODIS NDVI time series. Eur. J. Remote Sens. 2013, 46, 40-59. [CrossRef]

79. Li, S.; Potter, C. Vegetation regrowth trends in post forest fire ecosystems across North America from 2000 to 2010. Nat. Sci. 2012, 04, 755-770. [CrossRef]

80. Schut, A.G.T.; Ivits, E.; Conijn, J.G.; Ten Brink, B.; Fensholt, R. Trends in global vegetation activity and climatic drivers indicate a decoupled response to climate change. PLoS ONE 2015, 10, 1-22. [CrossRef] [PubMed]

81. Suepa, T.; Qi, J.; Lawawirojwong, S.; Messina, J.P. Understanding spatio-temporal variation of vegetation phenology and rainfall seasonality in the monsoon Southeast Asia. Environ. Res. 2016, 147, 621-629. [CrossRef] [PubMed]

82. Verbesselt, J.; Hyndman, R.; Newnham, G.; Culvenor, D. Detecting trend and seasonal changes in satellite image time series. Remote Sens. Environ. 2010, 114, 106-115. [CrossRef]

83. Andersen, A.N.; Cook, G.D.; Corbett, L.K.; Douglas, M.M.; Eager, R.W.; Russell-Smith, J.; Setterfield, S.A.; Williams, R.J.; Woinarski, J.C.Z. Fire frequency and biodiversity conservation in Australian tropical savannas: Implications from the Kapalga fire experiment. Austral Ecol. 2005, 30, 155-167. [CrossRef] 
84. Higgins, S.I.; Bond, W.J.; February, E.C.; Bronn, A.; Euston-Brown, D.I.W.; Enslin, B.; Govender, N.; Rademan, L.; O'Regan, S.; Potgieter, A.L.F.; et al. Effects of four decades of fire manipulation on woody vegetation structure in savanna. Ecology 2007, 88, 1119-1125. [CrossRef] [PubMed]

85. Smit, I.P.J.; Asner, G.P.; Govender, N.; Kennedy-Bowdoin, T.; Knapp, D.E.; Jacobson, J. Effects of fire on woody vegetation structure in African savanna. Ecol. Appl. 2010, 20, 1865-1875. [CrossRef] [PubMed]

86. Nelson, A.; Chomitz, K.M. Effectiveness of strict vs. multiple use protected areas in reducing tropical forest fires: A global analysis using matching methods. PLoS ONE 2011, 6. [CrossRef] [PubMed]

87. Welch, J.R.; Brondízio, E.S.; Hetrick, S.S.; Coimbra, C.E.A. Indigenous Burning as Conservation Practice: Neotropical Savanna Recovery amid Agribusiness Deforestation in Central Brazil. PLoS ONE 2013, 8, e81226. [CrossRef] [PubMed]

88. Mistry, J.; Berardi, A.; Andrade, V.; Krahô, T.; Krahô, P.; Leonardos, O. Indigenous fire management in the cerrado of Brazil: The case of the Krahô of Tocantíns. Hum. Ecol. 2005, 33, 365-386. [CrossRef]

(C) 2018 by the author. Licensee MDPI, Basel, Switzerland. This article is an open access article distributed under the terms and conditions of the Creative Commons Attribution (CC BY) license (http:/ / creativecommons.org/licenses/by/4.0/). 